Article

\title{
Geological Map of the Tocomar Basin (Puna Plateau, NW Argentina). Implication for the Geothermal System Investigation
}

\author{
Rubén Filipovich ${ }^{1, * \mathbb{C}}$, Walter Báez ${ }^{1}$, Gianluca Groppelli ${ }^{2, * \mathbb{C}}$, Florencia Ahumada ${ }^{1}(\mathbb{D}$, \\ Luca Aldega ${ }^{3}{ }^{(1)}$, Raúl Becchio ${ }^{1}$, Gabriele Berardi ${ }^{4}$, Sabina Bigi ${ }^{3}{ }^{\circ}$, Chiara Caricchi ${ }^{5}$, \\ Agostina Chiodi ${ }^{1}$, Sveva Corrado ${ }^{4}$, Gianfilippo De Astis ${ }^{5}$, Arnaldo A. De Benedetti ${ }^{4}$ (D), \\ Chiara Invernizzi ${ }^{6}$, Gianluca Norini ${ }^{2}$, Michele Soligo ${ }^{4}$, Sara Taviani ${ }^{7}$, José G. Viramonte ${ }^{1}$ \\ and Guido Giordano ${ }^{2,4}$ \\ 1 Instituto de Bio y Geociencias del NOA (IBIGEO, UNSa-CONICET), Av. 9 de Julio 14, \\ A4405BBA Salta, Argentina; geowbsalta@gmaill.com (W.B.); ahumadaflor@hotmail.com (F.A.); \\ tatobecchio@yahoo.com (R.B.); agoch18@hotmail.com (A.C.); joseviramonte@yahoo.com.ar (J.G.V.) \\ 2 CNR Istituto di Geologia Ambientale e Geoingegneria, sezione di Milano, Via Mario Bianco 9, \\ 20131 Milan, Italy; gianluca.norini@cnr.it (G.N.); guido.giordano@uniroma3.it (G.G.) \\ 3 Dipartimento di Scienze della Terra, Sapienza Università di Roma, Piazzale Aldo Moro, 5, 00185 Rome, Italy; \\ luca.aldega@uniroma1.it (L.A.); sabina.bigi@uniroma1.it (S.B.) \\ 4 Dipartimento di Scienze, Università degli Studi di Roma Tre, Largo S. L. Murialdo 1, 00146 Rome, Italy; \\ gabriele.berardi@uniroma3.it (G.B.); sveva.corrado@uniroma3.it (S.C.); \\ arnaldoangelo.debenedetti@uniroma3.it (A.A.D.B.); michele.soligo@uniroma3.it (M.S.) \\ 5 Istituto Nazionale di Geofisica e Vulcanologia, 00143 Rome, Italy; chiara.caricchi@ingv.it (C.C.); \\ gianfilippo.deastis@ingv.it (G.D.A.) \\ 6 Scuola di Scienze e Tecnologia-Sezione di Geologia, Università di Camerino, Via Gentile III da Varano, \\ 62032 Camerino, Italy; chiara.invernizzi@unicam.it \\ 7 Department of Earth and Environmental Sciences, University of Milano-Bicocca, 20126 Milan, Italy; \\ gua_colda@yahoo.com \\ * Correspondence: rubenfilipovich@yahoo.com.ar (R.F.); gianluca.groppelli@cnr.it (G.G.)
}

Received: 31 July 2020; Accepted: 14 October 2020; Published: 20 October 2020

check for updates

\begin{abstract}
This paper presents a detailed geological map at the 1:20,000 scale of the Tocomar basin in the Central Puna (north-western Argentina), which extends over an area of about $80 \mathrm{~km}^{2}$ and displays the spatial distribution of the Quaternary deposits and the structures that cover the Ordovician basement and the Tertiary sedimentary and volcanic units. The new dataset includes litho-facies descriptions, stratigraphic and structural data and new ${ }^{234} \mathrm{U} /{ }^{230} \mathrm{Th}$ ages for travertine rocks. The new reconstructed stratigraphic framework, along with the structural analysis, has revealed the complex evolution of a small extensional basin including a period of prolonged volcanic activity with different eruptive centres and styles. The geological map improves the knowledge of the geology of the Tocomar basin and the local interplay between orogen-parallel thrusts and orogen-oblique fault systems. This contribution represents a fundamental support for in depth research and also for encouraging geothermal exploration and exploitation in the Puna Plateau region.
\end{abstract}

Keywords: geothermal exploration; U/Th dating; Southern Central Andes; central Puna

\section{Introduction}

In the last decades a worldwide renewed interest in the use of geothermal energy has been stimulated by the increasing energy demand, the cost rise in production of fossil fuels and its environmental impacts and the technological advances in exploration and exploitation of geothermal 
resources [1,2]. The development of geothermal prospects in north-west Argentina and other Andean regions is a very important goal, given the presence of large heat anomalies associated with the magmatic arc (Figure 1). The widespread recent volcanic activity defines a variable-width Andean geothermal belt of anomalous heat flux $\left(>150 \mathrm{~mW} / \mathrm{m}^{2}\right)$ that are inferred to host vast high-temperature geothermal resources [3]. In addition, to the east, numerous thermal springs are located along the frontal structures of the Andean retro-wedge (Figure 1), although related to normal to slightly anomalous geothermal gradient, e.g., [3-5]. Despite these favourable geological conditions and its high potential, the Andes still represent the largest undeveloped geothermal region in the world due to financial and technical barriers as well as geoscientific aspects [6]. Nowadays, geothermal resources in Argentina have not been exploited on a large scale and rarely they have been directly used [7]. This is due mostly to the lack of detailed surficial geological information in several geothermal areas limiting the development of accurate conceptual models and interpretation of the available geophysical and geochemical data. In this sense, in recent years several research groups and private companies have revealed the existence of numerous sites of interest for geothermal exploitation in north-west Argentina, e.g., [4,5,8-13].

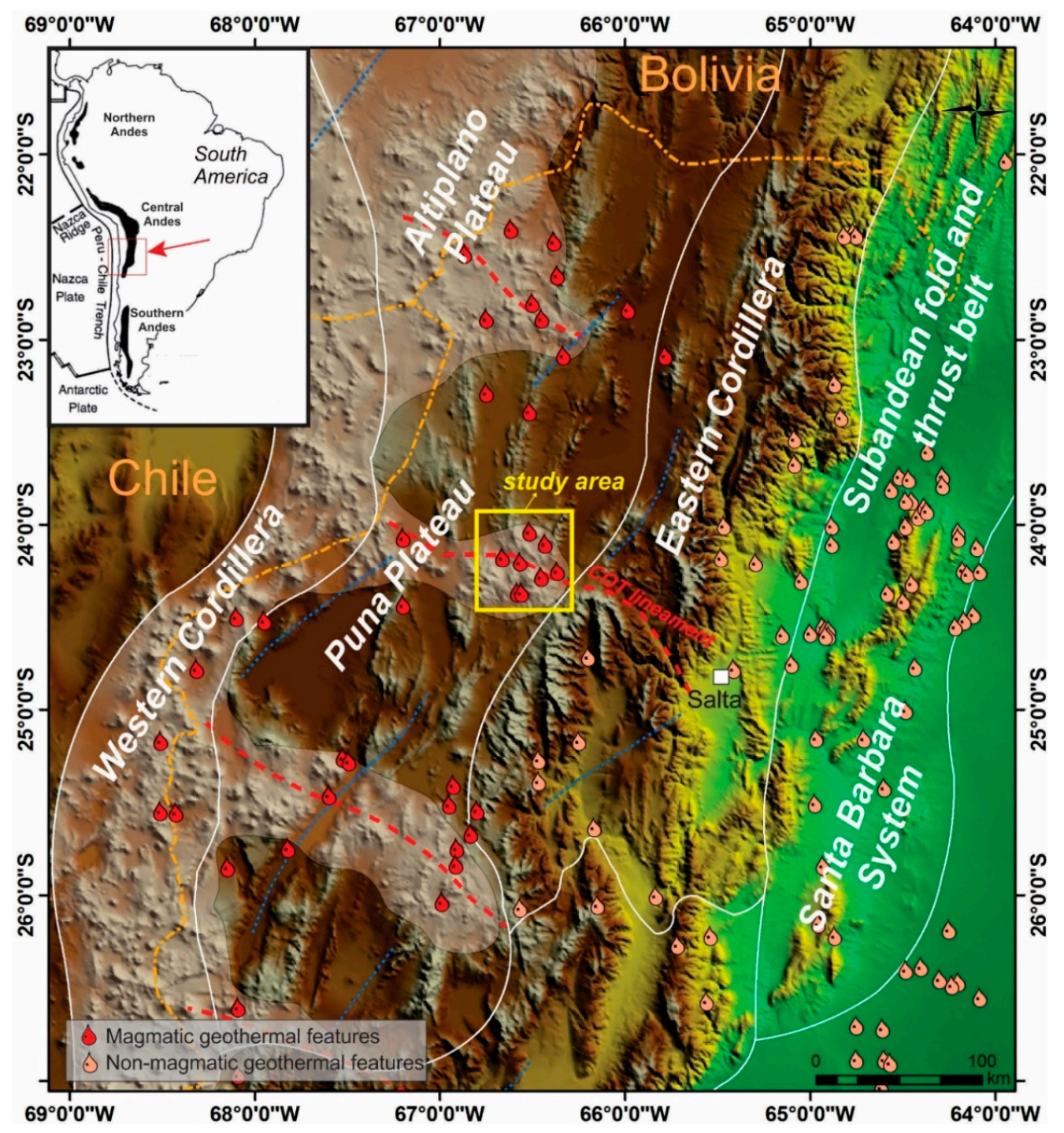

Figure 1. Geographic location of the study area (yellow box) and major morphotectonic units. The main transverse structures are depicted in red (NW-SE) and blue (NE-SW) dashed lines. The upper left inset shows the magmatism segmentation along the Andes and the location of Figure 1. COT: CalamaOlacapato-El Toro. 
One of the most promising geothermal prospects in north-western Argentina is the Tocomar Geothermal Field (TGF) [8,14], alongside with other systems in the Puna region [13] and in the Subandean fold-and thrust belt $[4,5,10,11]$. The TGF is located in the Puna plateau across the NW-SE-trending Calama-Olacapato-El Toro (COT) lineament [15-18], one of the major active tectonic lineament in the Central Andes (Figures 1 and 2). The area shows evidence of sub-aerial and sub-surface geothermal manifestations, including numerous hot-springs, sinters-travertine deposits, along with a profuse Quaternary volcanism [19-21]. Previous works in the Tocomar basin were mainly focused on geophysical [22-24], geochemical and volcanological characterization of the eruptive centres and its products [19-21,25-27], as well as outlining schematic conceptual models for the TGF [8,28]. In spite of this, available geological maps [29-31] and field-based structural works $[18,32,33]$ have been carried out at a regional scale (e.g., 1:250,000). Thus, a more detailed field mapping $(1: 20,000)$ integrated by ${ }^{234} \mathrm{U} /{ }^{230} \mathrm{Th}$ chronological data may contribute to refine the stratigraphic and structural framework that, ultimately, is fundamental for: (i) understanding the relationships among cap rocks, reservoirs and fluid circulation, (ii) assessing the geothermal potential and age of mineralization and (iii) planning resource investigation and exploitation reducing risk and uncertainty during exploration stage.

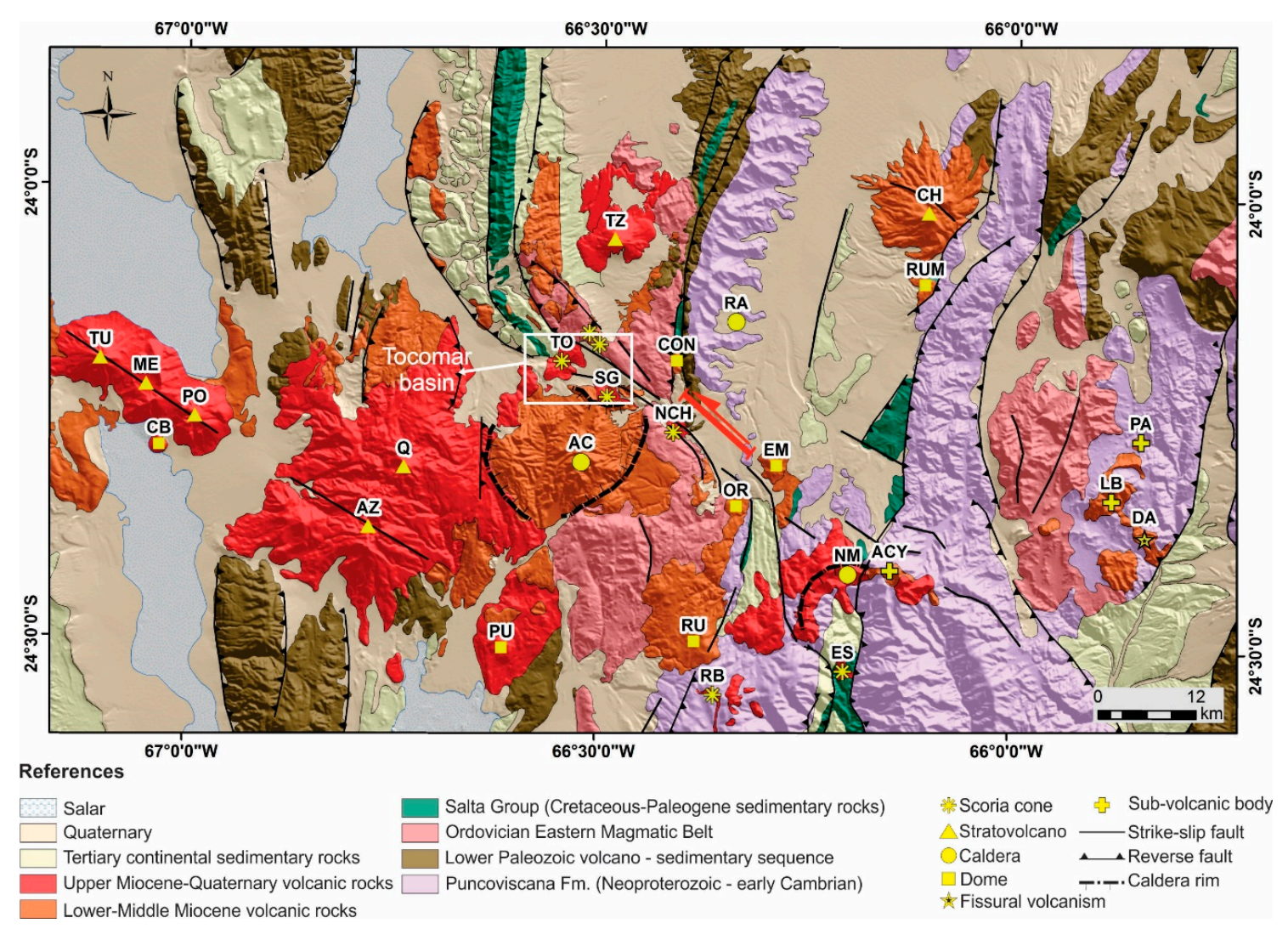

Figure 2. Simplified geological map of the Central Puna ( 24 S) (modified from [18]). The location of the Tocomar basin and the geological map is shown with a white box. TU: Tul Tul; ME: Del Medio; PO: Pocitos; CB: Cerro Bola; AZ: El Azufre; Q: Quevar; PU: Pucara; RU: Rupasca; AC: Aguas Calientes; OR: Organullo; NCH: Negro del Chorrillo; SG: San Jerónimo; TO: Tocomar; TZ: Tuzgle; CON: Concordia; RA: Ramada; EM: El Morro; NM: Negra Muerta; NAC: Nevado de Acay; CH: Chimpa; RUM: Rumio; PA: Pancho Arias; LB: Las Burras; DA: Diego de Almagro; OC: Olacapato; SRP: Santa Rosa de los Pastos Grandes; SAC: San Antonio de los Cobres; SRT: Santa Rosa de Tastil; EM: El Moreno.

This paper presents a new geological map (scale 1:20,000) and a detailed revision of the stratigraphy of the Tocomar basin (see Supplementary Materials Figure S1). The new dataset includes litho-facies description and geochronology of Ordovician-Cenozoic units. Furthermore, the role of orogen-parallel 
and orogen-oblique faults is evaluated in order to provide insights into the structural framework and evolution of the Tocomar basin.

\section{Geological Setting}

The Tocomar basin is located in central Puna ( $24^{\circ} \mathrm{S}$, NW Argentina), in the back-arc of the Central Andes (Figure 1). The Puna plateau is an internally drained plateau with an average elevation of about $3800 \mathrm{~m}$, bounded to the west by the active magmatic arc (Western Cordillera), and to the east by the Eastern Cordillera and the Subandean ranges (Figure 1). Since the Eocene-Oligocene, the Puna plateau formed by crustal shortening and thickening, with both orogen-parallel thrusting and orogen-oblique strike-slip faulting associated with magmatism, delamination of the thickened lower crust and mantle lithosphere, and, subordinately, gravity-driven crustal channel flow, e.g., [18,34-38]. The Puna plateau is characterized by an extensive magmatism since Neogene time $[39,40]$. The north-south volcanic arc initially developed along the Maricunga belt and finally established $50 \mathrm{~km}$ to the east in the modern Central Volcanic Zone (Western Cordillera) [39]. Shallowing of the subducting slab explains the eastward broadening of the arc magmatism along regional NW-SE, vertical strike-slip faults systems [39,41-47]. Moreover, the orogen-parallel thrust faults played a key role for the emplacement of polygenetic volcanoes in the back-arc setting as recently proposed by Norini et al. [18,48]. One of the main NW-SE tectonic structures exposed in the area is the COT, spatially coincident with the Quevar Transversal Volcanic Chain [41]. The COT is an active left-lateral fault system developed as a transfer structure connecting some of the orogen-parallel thrusts that in turn stack the Precambrian-Ordovician units onto the Cretaceous to recent sedimentary and volcanic rocks [18] (Figure 2). The orogen-oblique COT fault system and the orogen-parallel faults are part of the same tectonic system [18] developed along Paleozoic ductile deformation zones [38] with a peak of deformation during Miocene time [21].

The oldest central Puna basement is mainly composed by highly deformed meta-pelites and meta-arenites of the late Neoproterozoic to early Cambrian Puncoviscana Formation [49,50] (Figure 2). On top, the Cambrian siliciclastic sediments of the Mesón Group are exposed in a few outcrops in the eastern sector of the central Puna [29,51,52] (Figure 2). The Precambrian and Cambrian units are intruded by metagranitoid rocks of the Ordovician Faja Eruptiva, Oire Formation or Eastern Magmatic Belt [53] and unconformably covered by an Ordovician volcano-sedimentary sequence [29,54-57] (Figure 2). Above, the poly-deformed pre-Cambrian and Palaeozoic basement rocks, the Cretaceous-Paleocene syn- and post-rift sedimentary sequence of the Salta Group and the Tertiary siliciclastic and evaporitic deposits of the Pastos Grandes Group related to the Andean broken foreland basin evolution were deposited [25,49,58-63] (Figure 2). The base of the Pastos Grandes Group is represented by a $>2 \mathrm{~km}$ thick, purple to bright red, up-section coarsening, fluvial and alluvial sequence related to the Geste Formation $[61,63,64]$. The volcanic activity in the central Puna, middle Miocene in age with a peak at about $10 \mathrm{Ma}$, (Figure 2) is represented by andesitic-dacitic stratovolcanoes [48,65-67], and ignimbrites and domes of dacitic-rhyolitic composition in most cases associated with collapse caldera, e.g., [68,69]. Particularly, the Tocomar basin shows Quaternary bimodal volcanism that includes rhyolitic centres such as Tocomar Volcanic Centre $[19,20]$ and the San Jerónimo shoshonitic-andesitic monogenetic volcano [70].

\section{Methodology}

The exceptional exposure and the lack of vegetation in the high-altitude hyperarid Puna region allowed a detailed field survey and the drawing up of a 1:20,000-scale geological map of the Tocomar basin. As a first step, available geological maps $[8,18,29,33,68]$ were georeferenced and compiled in a geographical information system (GIS). Moreover, an exhaustive reappraisal of previously described volcanic units [20] was carried out.

The geological map presented in this study is the result of five field surveys carried out in the 2014-2016 period integrated with remote sensing (mainly Google Earth and Esri basemapsDigitalGlobe satellite images). The field survey was based on lithostratigraphic units, as recommended 
by the International Stratigraphic Guide (ISG) [71] and successfully applied in most recent geological maps of volcanic areas [72-75]. To identify and/or define the lithostratigraphic units exposed in the Tocomar area, we described more than 220 outcrops (green points in the 1:100,000 scale geological map), logged numerous stratigraphic sections and finally reconstructed a composite stratigraphic section of the entire Tocomar basin (Figure 3). Accurate stratigraphic correlations were performed for the volcanic units whereas the lack of marker beds and scattered outcrops prevented an accurate stratigraphic correlation for the sedimentary units. According to the recommendations of ISG [71] we applied two different ranks of lithostratigraphic units: members when we recognised a lithological variation, and formations. The lithostratigraphic units have been grouped in the Tocomar (Pleistocene) and Pre-Tocomar basin units (Ordovician to Miocene) to highlight the evolutionary steps of the area and show off the Pleistocenic volcanic activity responsible for the present-day active geothermal system. In addition, the colours chosen to display the lithostratigraphic units into the geological map follow the same concept: the Tocomar basin units present marked colours (from yellow to red) to underline the Quaternary volcanic deposits.

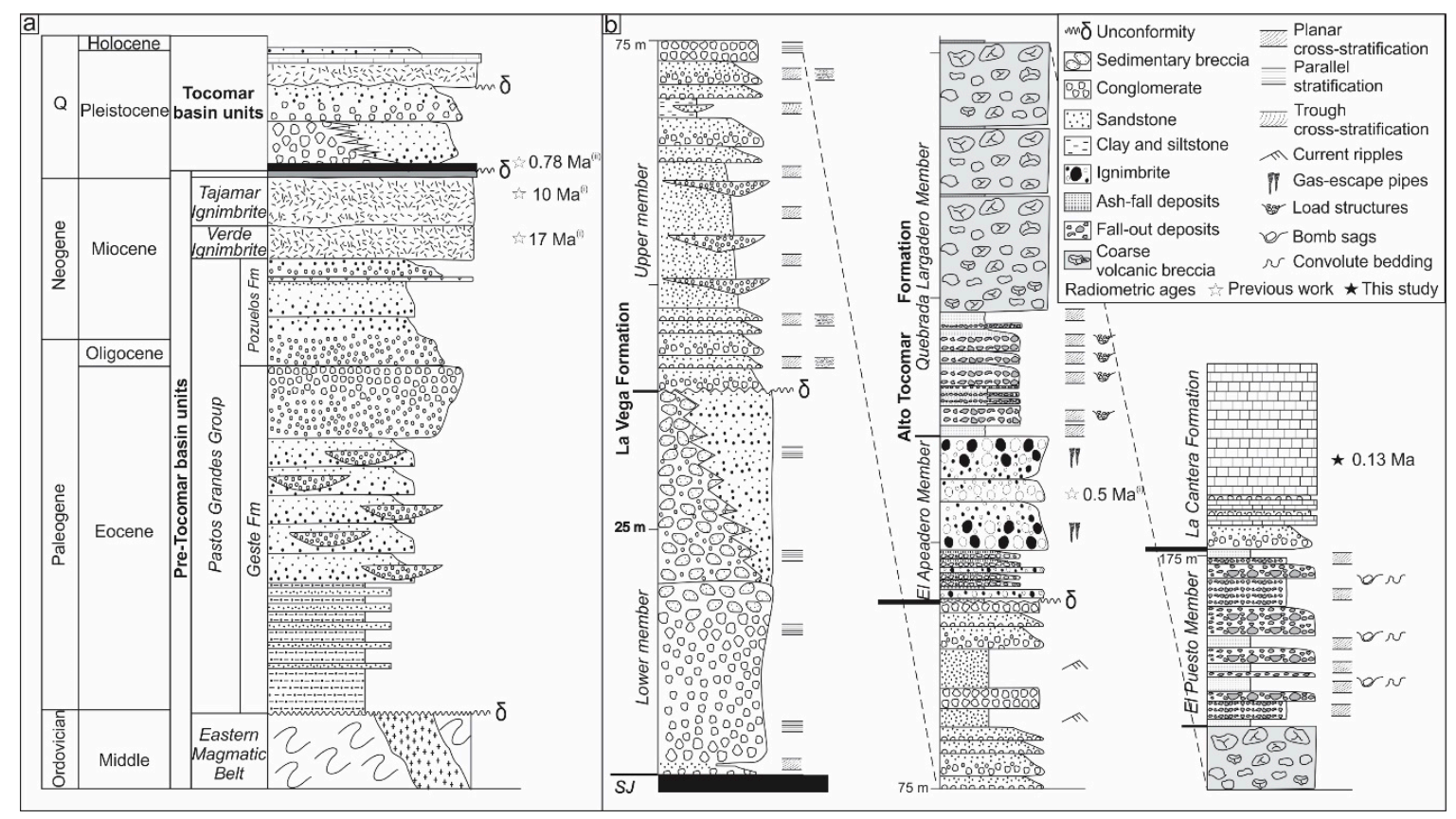

Figure 3. (a) Schematic stratigraphic log of the studied area. Ages (i) [43]; (ii) [25]; (b) composite stratigraphic log for the Tocomar basin. SJ: San Jerónimo.

We plotted two geological maps, one at 1:100,000 scale, fundamental as general overview of the geology of the area, and the second one, focused on the Tocomar basin, at 1:20,000 scale. To realise the geological inset at 1:100,000, we used data from literature [68] for the Miocene Cerro Agua Calientes Caldera or remote sensing interpretation to complete the geological map for inaccessible areas. The main structures with special emphasis on their kinematics and timing were described in the field and allowed us to unravel the interplay between the frontal thrusts and COT-like faults. All the geological, stratigraphical and structural data were organised in a GIS environment to combine the data of the different field works and to realise the geological map.

${ }^{234} \mathrm{U} / 230 \mathrm{Th}$ analyses of travertine samples were performed at the Laboratory of Environmental and Isotopic Geochemistry of Roma Tre University. The age of the samples has been determined with $\mathrm{a}^{232} \mathrm{Th} /{ }^{230} \mathrm{Th}$ activity ratio higher than 80 , free from non-radiogenic ${ }^{230} \mathrm{Th}$, using the ${ }^{234} \mathrm{U} /{ }^{230} \mathrm{Th}$ and ${ }^{238} \mathrm{U} /{ }^{234} \mathrm{U}$ activity ratio of calcite samples. In contrast, ages obtained for samples with a ${ }^{232} \mathrm{Th} /{ }^{230} \mathrm{Th}$ activity ratio lower than or equal to 80 for the presence of non-radiogenic ${ }^{230} \mathrm{Th}$ related to detrital ${ }^{232} \mathrm{Th}$ required a correction performed assuming that all detrital Th had an average ${ }^{232} \mathrm{Th} /{ }^{230} \mathrm{Th}$ activity 
ratio of $0.85 \pm 0.36$ [76] (Table 1). The isotopic complexes of $U$ and Th have been extracted according to the procedure described by Edwards et al. [77] and then analysed through alpha-counting, using high-resolution ion-implanted Ortec silicon-surface barrier detectors.

Table 1. Uranium abundance, uranium and thorium activity ratios and ages of samples from Tocomar Geothermal Field (TGF)-related travertines. ${ }^{*}$ The $\left({ }^{230} \mathrm{Th} /{ }^{234} \mathrm{U}\right)$ was corrected using the crustal thorium mean composition, $0.85 \pm 0.36$ [76], for samples with a ${ }^{230} \mathrm{Th} /{ }^{232} \mathrm{Th}$ activity ratio lower than 80 . Analysis performed at the Laboratory of Environmental and Isotopic Geochemistry of Roma Tre University, Italy.

\begin{tabular}{cccccccc}
\hline Sample & $\begin{array}{c}\text { Coordinates } \\
\text { (Lat.-Lon.) }\end{array}$ & $\mathbf{U}(\mathbf{p p m})$ & ${ }^{230} \mathrm{Th} /{ }^{232} \mathbf{T h}$ & ${ }^{234} \mathrm{U} /{ }^{238} \mathrm{U}$ & ${ }^{230} \mathbf{T h} /{ }^{234} \mathbf{U}$ & $\begin{array}{c}\left.{ }^{230} \mathbf{T h} /{ }^{234} \mathbf{U}\right) \\
\text { Corrected }\end{array}$ & Age (ka) \\
\hline \multirow{2}{*}{ AR1 } & $24.187038 ;$ & $0.196 \pm 0.011$ & $185.493 \pm 20.345$ & $1.190 \pm 0.058$ & $0.703 \pm 0.047$ & - & $126 \pm 15$ \\
& -66.563940 & & & & & \\
AP09 & $-24.187993 ;$ & $0.019 \pm 0.001$ & $10.056 \pm 1.019$ & $10.056 \pm 1.019$ & $0.798 \pm 0.033$ & $0.783 \pm 0.084$ & $161 \pm 30$ \\
\hline
\end{tabular}

\section{Stratigraphy of the Tocomar Area}

The stratigraphic record in the study area was subdivided into Pre-Tocomar and Tocomar basin units (Figure 3a,b). A systematic description based on previous works and new field observations of the mapped lithostratigraphic units is presented in the following paragraphs. New geochronological data for the Tocomar basin units are also provided.

\subsection{Pre-Tocomar Basin Units}

\subsubsection{Eastern Magmatic Belt (Ordovician) (1a, 1b)}

The oldest rocks mapped in the Tocomar area are porphyric and equigranular granites and granodiorites with mafic dike intrusions and mylonites that form the so-called Ordovician "Faja eruptiva de la Puna Oriental", "Complejo Eruptivo Oire" [16,29,55,57,78] or "Eastern Magmatic Belt" [53] (Figure 4a). This unit mainly crops out in the north-east sector of the study area forming a high altitude ridge developed at more than $4500 \mathrm{~m}$ a.s.l. (Alto de Chorrillos, main map).

\subsubsection{Geste Formation (Middle-Late Eocene) (2)}

In the study area, toward the north-west of the Tocomar basin (main map), an upward coarsening sequence with a typical red-purple to bright red colour crops out (Figure $4 \mathrm{~b}$ ). The main lithofacies are characterized by fine-grained fluvial sandstones and mudstones and poorly sorted conglomerates (Figure $4 \mathrm{~b}$ ). The base of the succession is mainly made of massive siltstones interbedded with lenses of fine- to medium-grained sandstone. The middle part of the succession is characterized by fine- to coarse-grained sandstones, locally gravelly, intercalated with lens of pebble to cobble, clast-supported, conglomerates with erosional bases and fining upward arrangement. The upper part of the succession shows coarser sediments made up of thick beds of cobble to boulder, clast- to matrix-supported conglomerates. From bottom to top, the succession shows an upward-shallowing of dip angles from $65^{\circ}$ to $40^{\circ}$ towards NE. The minimum thickness of the succession along the "El Oculto" gully was estimated in about $1200 \mathrm{~m}$ (main map). These thickness estimations were carried out taking into account bedding attitudes (main map) by using bedding attitudes. This unit is in tectonic contact with deposits of the younger Pozuelos Formation in the footwall. Due to the lack of stratigraphic markers, radiometric dating, intense tectonics and hydrothermal activity, it is difficult to correlate this formation with other units. 


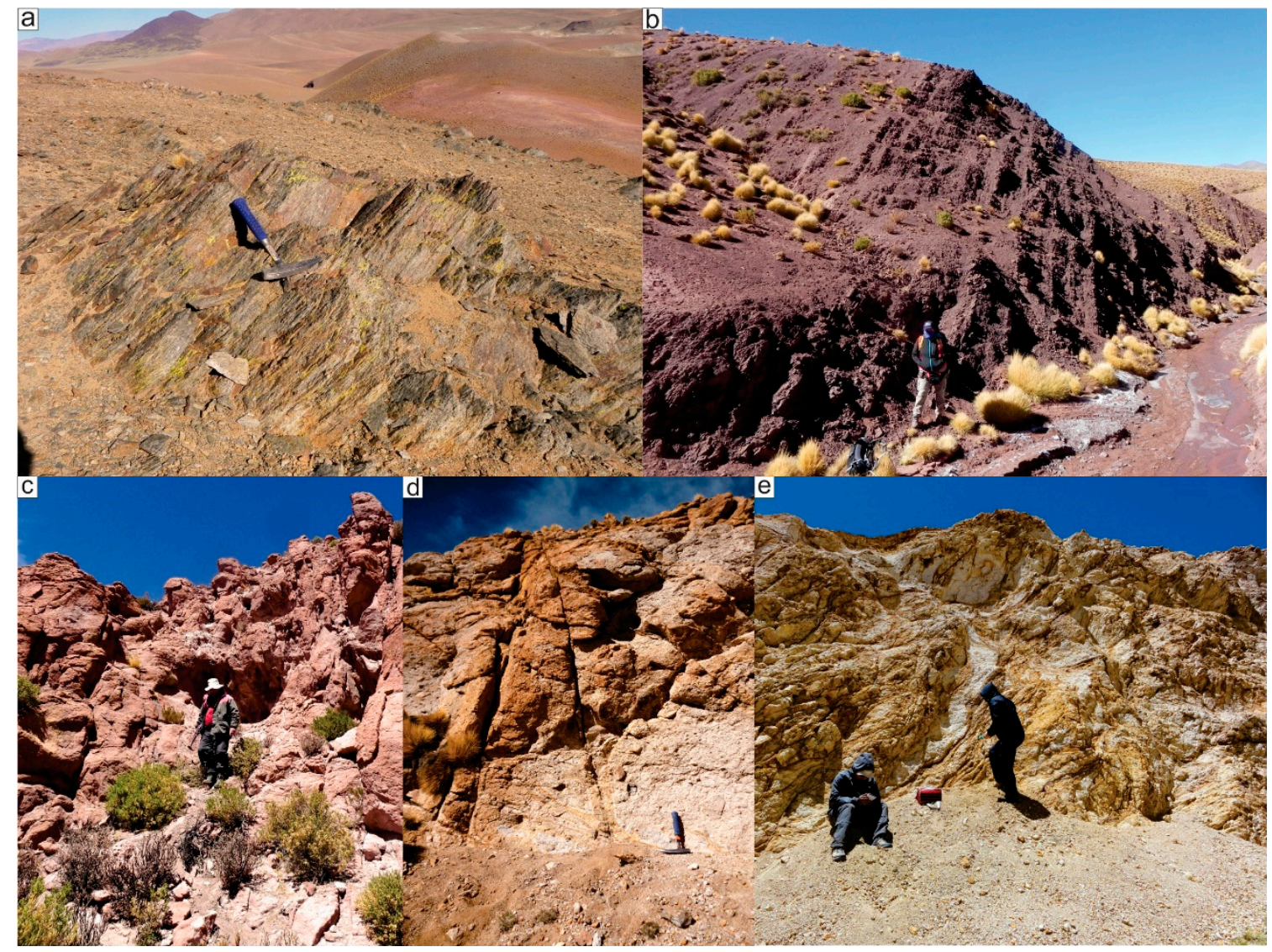

Figure 4. Field views of the pre-Tocomar basin units. (a) Ordovician meta-volcanic rocks. (b) Alternating dark reddish siltstone and fine-grained sandstones from the Geste Formation. (c-e) Unaltered, partially and highly altered Tajamar Ignimbrite, respectively.

At the present time, there is no consensus on the stratigraphic position of the purple red sedimentary rocks exposed in the study area. Several authors mapped these rocks either as Cerro Morado Formation of Eocene age [31], undifferentiated Cretaceous Pirgua Subgroup [8,18,79-82] or undifferentiated Pastos Grandes Group of Tertiary age [29]. However, the overall features of the outcropping deposits suggest that these rocks may be related to the Geste Formation [28] based on the following evidence: (i) lithofacies association and colour such as well bedded red to purple, basement derived, continental fine- to medium grained sandstone and siltstone to conglomerate, (ii) upward coarsening trend, (iii) up-section decreasing in dip angles and (iv) thickness. Furthermore, similar deposits were described toward the south, about $55 \mathrm{~km}$ along strike, in the Pastos Grandes Salar, being assigned to the foreland-related deposits of the middle Eocene Geste Formation $[61,63]$ (Figure 2). Likewise, Seggiaro et al. [30] assigned similar deposits to Casa Grande Formation (Eocene) further North along the Tanque ridge, pointing out the complexity of its stratigraphic position.

\subsubsection{Pozuelos Formation (Middle-Late Miocene) (3)}

This unit consists of a thick reddish/greyish continental succession of alluvial/fluvial deposits formed by conglomerates, fine-grained sandstones and siltstones with minor intercalations of limestones and pyroclastic beds. This unit is formed by isolated outcrops of Tertiary sedimentary rocks covered by talus and Cerro Aguas Calientes ignimbrites to the top. The Pozuelos Formation shows evidences of deposition in more arid conditions within closed drainage basins [61] in contrast to the Geste Fm., whose depositional setting is related to unconfined flows in a sandy to gravelly braided fluvial system [63] with lack of volcanic layers. 


\subsubsection{Cerro Aguas Calientes Caldera ignimbrites (Middle Miocene) $(4,5)$}

The Cerro Aguas Calientes caldera (main map) is a polygenetic, tectonically controlled collapse caldera, which comprises two main eruptive episodes, that produced dacitic crystal-rich ignimbrites. The first event occurred at $17.15 \pm 0.5 \mathrm{Ma}$ (Verde Ignimbrite) and the second one at 10.3 Ma (Tajamar Ignimbrite) $[43,68]$ with a total minimum volume of ca. $490 \mathrm{~km}^{3}$ (DRE) (Figure 4c). Both units are homogeneous pumice-rich deposits, strongly welded and with a devitrification signature [68] (Figure 4c). The Verde ignimbrite (4, main map) is dark to pale green in colour, and ranges in thickness from $520 \mathrm{~m}$ (intracaldera facies, non-exposed base) to $80 \mathrm{~m}$ (outflow facies) [68]. The Tajamar ignimbrite (5, main map) is red to pale pink in colour and shows variable thickness between $570 \mathrm{~m}$ (intracaldera facies) and $<130 \mathrm{~m}$ (outflow facies) [68] (Figure 4c). The Tajamar Ignimbrite has an extensive areal distribution with different degrees of alteration, from fresh to partially altered (Figure 4c,d) to highly altered (argillic alteration, Figure 4e). The outcrops encircle the Tocomar basin and unconformably cover the Eastern Magmatic Belt and Geste Formations (main map). The Tajamar Ignimbrite is mainly covered by recent alluvial deposits and fluvially-reworked volcaniclastic deposits.

\subsubsection{El Oculto Formation (Upper Miocene) (6)}

This unit consists of several hydrothermal alteration zones and porphyric dacitic dike intrusions probably related to the Punta del Viento domes of 11.8 Ma (K/Ar age) [83] (main map). The dacitic intrusions, striking $\mathrm{N} 60^{\circ}$, have thickness ranging from $1.5 \mathrm{~m}$ to $15 \mathrm{~m}$.

\subsubsection{Quevar Volcanic Complex (Upper Miocene) (7)}

In the south-western edge of the study area, a series of andesitic lava flows overlying the Cerro Aguas Calientes Caldera ignimbrites are exposed (main map). These rocks were assigned to the Quevar Volcanic Complex [65] based on their stratigraphic position, attitude and lithological features. The lavas associated with the Quevar activity have been dated, using the K/Ar method, at $8.0 \pm 0.2 \mathrm{Ma}$ to the west in the Mamaturi gorge and to $10.03 \pm 0.5$ in the Antuco area [84]. From the geomorphic features, the geometry, the height of the outcrops and the cross-sectional relationships with the rim of the Aguas Calientes caldera (main map), it is inferred that the lavas are tilted and displaced by subsequent tectonism.

\subsection{Tocomar Basin Units}

\subsubsection{San Jerónimo Formation (Middle Pleistocene) (8)}

A series of blocky lava flows from San Jerónimo scoria cone are exposed in the south-eastern edge of the Tocomar basin (Figure 5a). These lava flows of Pleistocene age (0.78 $\pm 0.1 \mathrm{Ma})$ [25] are shoshonitic basaltic andesites to andesites/trachyandesites, about $10 \mathrm{~m}$ thick [21,70]. The shoshonites show porphyritic texture with olivine and clinopyroxene phenocrysts and, subordinate, micro- to phenocrysts of plagioclase, hydrous minerals (biotite and amphibole) and xenocrysts of quartz, in a pilotaxitic to hialopilitic groundmass [85]. The lava flows rest on the Tajamar Ignimbrite along the northern caldera topographic margin and are overlapped by the Lower member of La Vega Formation.

\subsubsection{La Vega Formation (Middle to Late Pleistocene (?)) (9)}

It consists of a thick heteropic epi-volcaniclastic (sensu [86]) succession cropping out in the north-west edge of the basin, near the Tocomar river headwaters, and along the C-14 San Antonio de los Cobres-Socompa railway (Figure 5a). This unit consists of pale green/light red alluvial terraced deposits formed by poorly sorted conglomerates with volcanic sandstones and mudstones interbedded, and subordinate debris deposits. This unit was divided into two coarsening-upward members: Lower and Upper members (Figures $3 b$ and $5 a$ ). These two members were assigned to the same formation and are separated by an important lithological variation associated to an erosional 
phase in the Tocomar basin. The base of the formation rests unconformably on the Geste Formation and nonconformably upon the Cerro Aguas Calientes Caldera ignimbrites. At the top, a marked through-going erosive and angular unconformity points out the contact with the younger Alto Tocomar Formation (Figure 5a). The maximum thickness is about $90 \mathrm{~m}$. The relative age of this formation has been constrained by its stratigraphic relationship with the San Jerónimo lava flows (0.78 Ma) to the south-east, assigning a Middle to Late Pleistocene age.

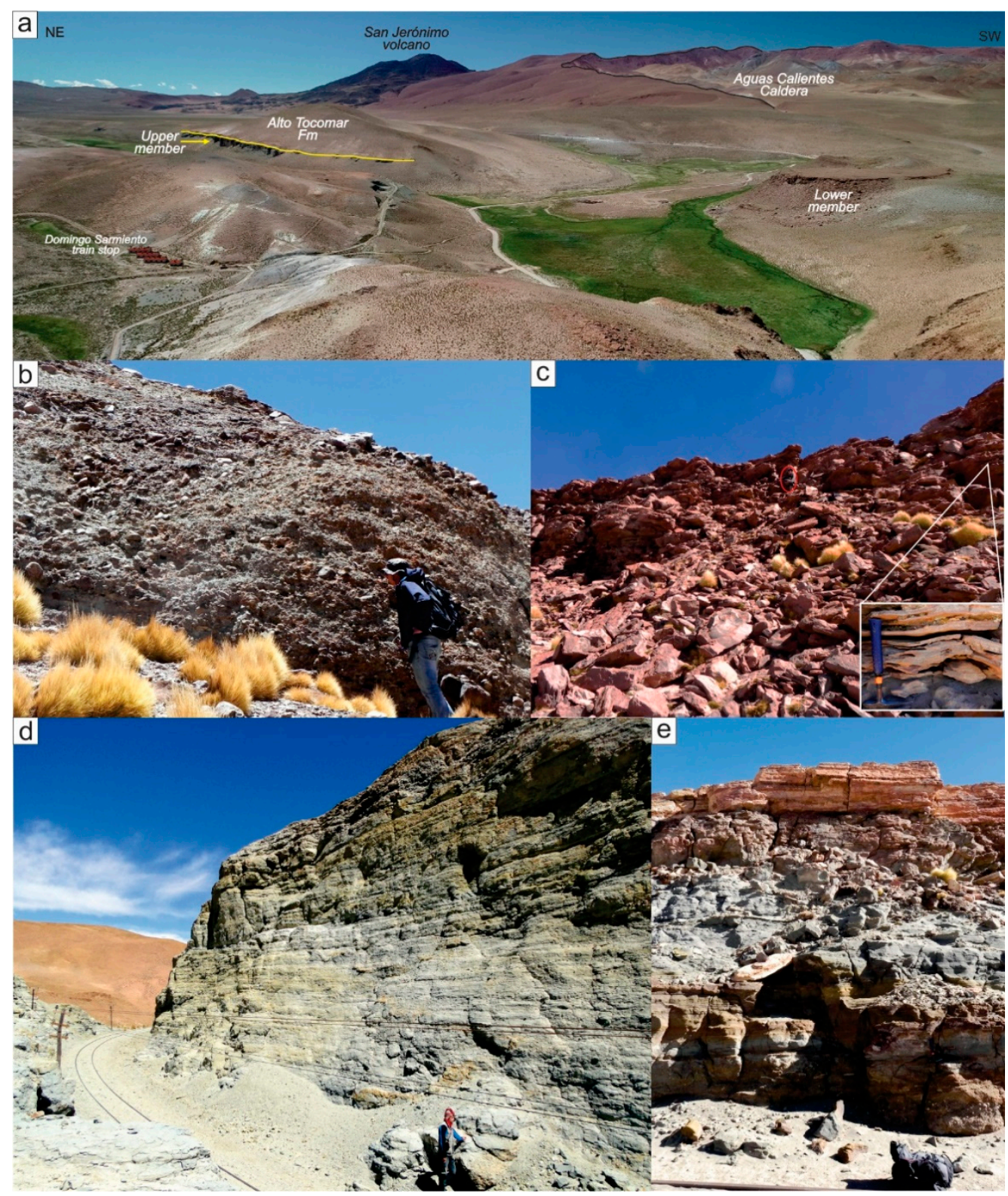

Figure 5. Field views of La Vega Formation. (a) Panoramic field photo. The boundary between the Upper member of La Vega and Alto Tocomar Formations is marked by a yellow solid line; (b) Basal deposits of the Lower member; (c) thin-bedded sandstones interpreted as lateral facies variation of the Lower member (person for scale highlighted in red ellipse). The inset shows a detailed view of the disturbed lamination in the sandstones; (d) Upper member polymictic conglomerates; (e) dark cross-bedded volcanic sandstones within the Upper member. 
Lower Member (9a)

It consists of terraced alluvial deposits made up of crudely stratified, polymictic, matrix-supported, poorly sorted conglomerate with angular to sub-rounded, irregularly sized, clasts from pebble to boulder size (Figure $5 b$ ). The clasts are largely formed by cobbles and boulders of granitoid rocks from the basement, ignimbrites and lavas, and occasionally sedimentary pebbles and cobbles supported by a hardened greyish sandy to fine gravel matrix (Figure $5 b$ ). The base of the sequence shows a slight normal grading that shifts upward to a $40 \mathrm{~m}$ structureless conglomerate interbedded with sandstone lenses. Toward the south-east, the succession grades upward to a tabular thin-bedded fine to coarse sandstone, along with fine-grained homogeneous deposits that represent distal alluvial fans dominated by hyperconcentrated sheet flows (Figure 5c). In addition, some horizons show soft-sediment deformation structures interpreted as seismites suggesting a syn-tectonic activity during the sedimentation of the upper succession (Figure 5c).

Upper Member (9b)

It is constituted by crudely stratified polymictic conglomerates, sandstones, gravelly sandstones and with a minor amount of mudstones (Figure 5d). The Upper member shows a basal fining-up section and an upper coarsening-up section. Locally, dark cross-bedded volcanic sandstones are interbedded towards the top of the upper section (Figure 5e). In the central part of the Tocomar basin, fluvial incisions expose about $40 \mathrm{~m}$-thick of a coarse-grained sedimentary succession (minimum thickness for base unexposed) (Figure 5a). The Upper member onlaps the underlying Cerro Aguas Calientes Caldera ignimbrites and the Lower member, filling an important palaeotopography (Figure 5a). The Upper member is interpreted as a stream-channel alluvial fan formed by stream flows and hyperconcentrated flows.

\subsubsection{Alto Tocomar Formation (Middle-Upper (?) Pleistocene) (10)}

It consists of a complex volcanic succession made up of small-volume ignimbrites, pyroclastic surges and fall deposits of rhyolitic composition generated by two $[20,27,83]$ or three eruptive episodes (this work, Figure 6). In this paper, this succession has been subdivided into three members: El Apeadero, Quebrada Largadero and El Puesto members based on their geometry and juvenile and lithic clast contents (Figure 6). The formation is mainly exposed along the C-14 railroads and between Alto Tocomar and Tocomar river headwaters showing a roughly triangular shape developed mainly northward (see geological map). The maximum thickness is about $120 \mathrm{~m}$. Radiometric ages for El Apeadero member are $1.15 \pm 0.3 \mathrm{Ma}(\mathrm{K} / \mathrm{Ar})[25]$ and $0.55 \pm 0.1 \mathrm{Ma}\left({ }^{40} \mathrm{Ar} /{ }^{39} \mathrm{Ar}\right)[43]$.

\section{El Apeadero Member (10a)}

This unit corresponds to the first eruptive episode reported in Petrinovic and Colombo Piñol [20]. The El Apeadero member is characterized by high contents of juvenile clasts made up of pumice and dense glassy clasts. It consists of alternating pyroclastic density currents (PDCs) deposits, thinly bedded pyroclastic-surge deposits, and tephra and tuff deposits made up of lapilli and coarse ash (Figure 6a), well exposed at Domingo F. Sarmiento train stop (Figure 5a). These pyroclastic deposits are interpreted as related to a rhyolitic phreato-plinian eruption. Due to pre-eruptive topography, the ignimbrite shows massive valley-pond facies in topographic lows and thinner stratified veneer facies along topographic ridges. The El Apeadero member covers La Vega formation with a mild angular unconformity (Figure 5a). The maximum thickness is about $45 \mathrm{~m}$. 


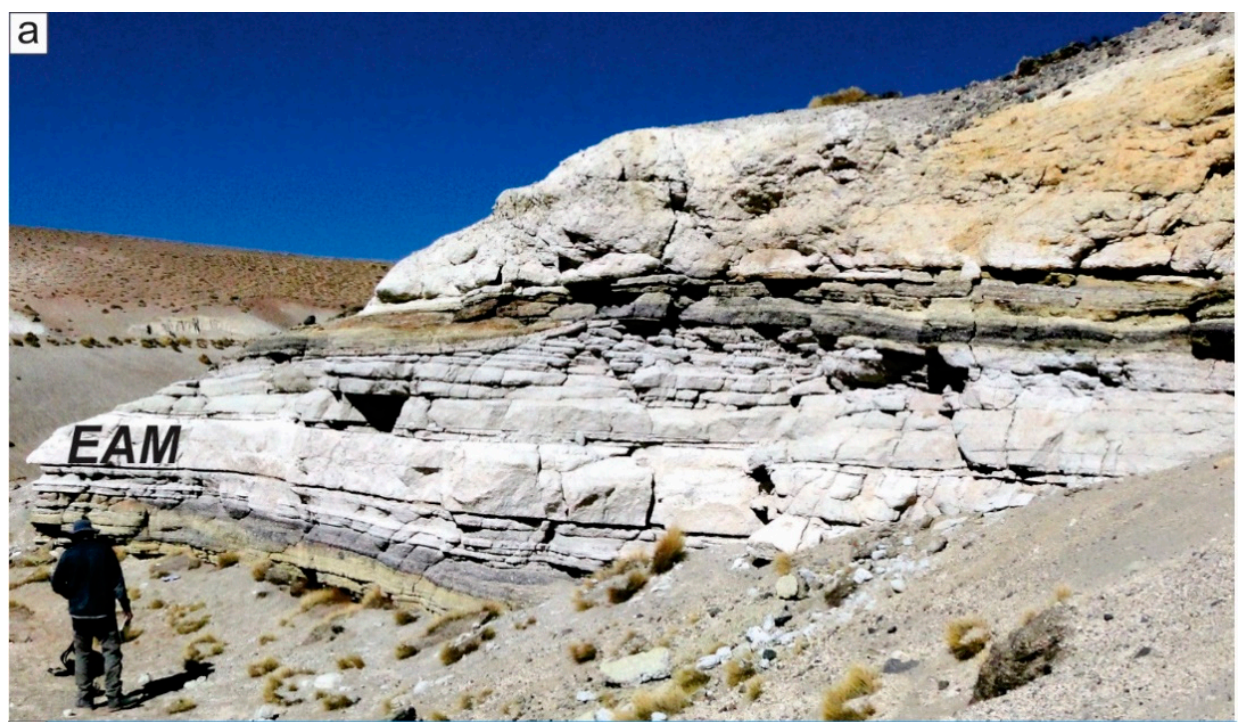
b

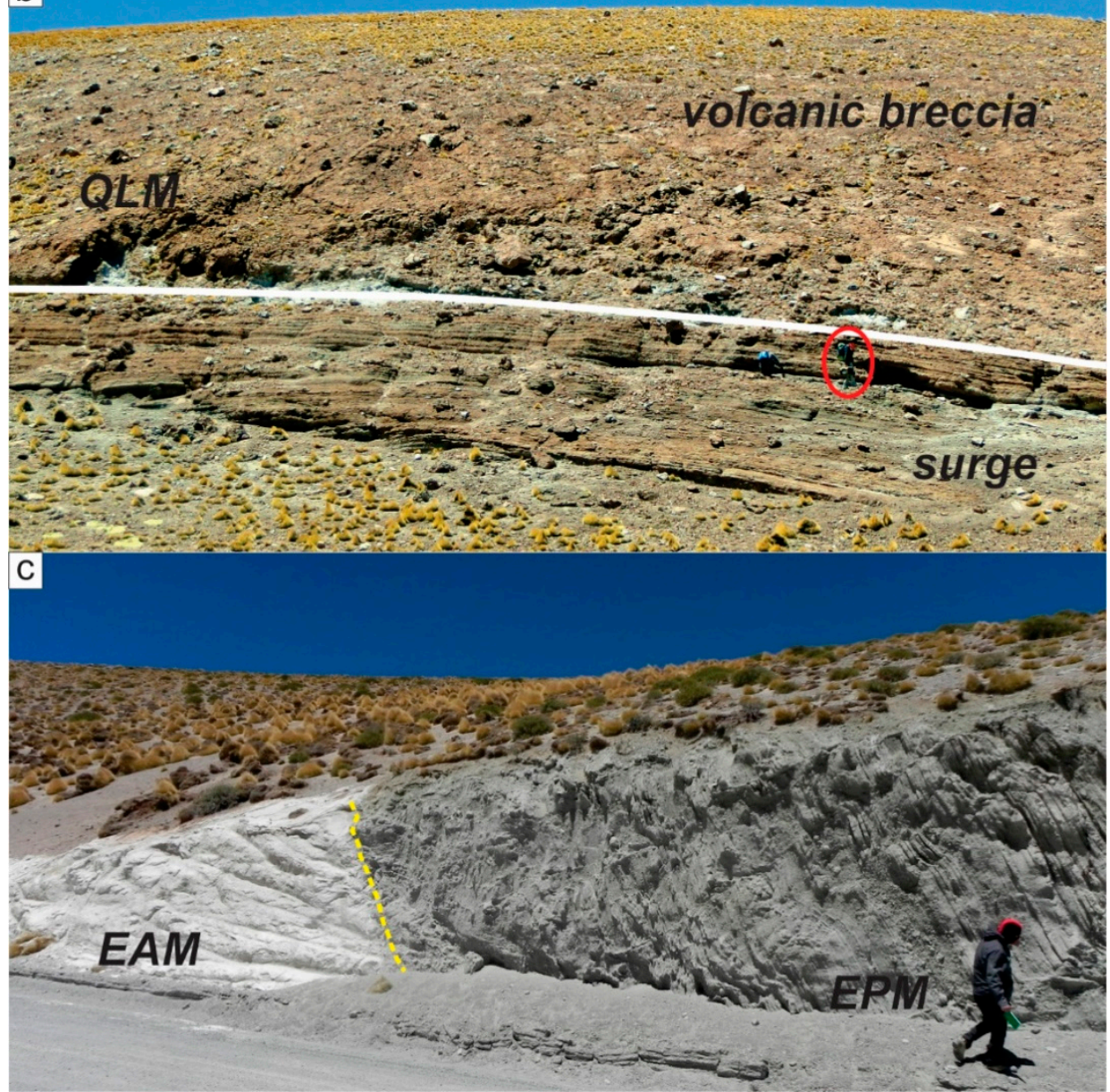

Figure 6. Field views of the Alto Tocomar Formation. EAM: El Apeadero member; QLM: Quebrada Largadero member; EPM: El Puesto member. (a) Ash-fall deposits and tephra layers intercalated within pyroclastic density current deposits from El Apeadero member; (b) Quebrada Largadero member (person for scale highlighted in red ellipse). Note the marked reverse grading from well-bedded pyroclastic deposits to boulder volcanic breccia; (c) well-stratified volcanic deposits of the El Puesto member. The contact with the deposits of the El Apeadero member is marked by the yellow dashed line. 
Quebrada Largadero Member (10b)

This succession was previously described as proximal facies of the first eruptive episode [20] cropping out from the north to the south along the Tocomar river valley (main map). At the base, it is made up of a well-bedded pyroclastic surge deposit that grades upward to a massive, often hardened, clast-supported fines-rich primary volcanic breccia, about $35 \mathrm{~m}$ thick (Figure $6 \mathrm{~b}$ ). It is made up of about $80 \%$ lava blocks that show porphyritic texture with abundant phenocrysts of quartz and subordinate biotite and plagioclase in an unaltered/fresh glassy matrix, inferred as juvenile clast. The lithic blocks, composed of Ordovician basement fragments, represent lower than $20 \%$ of the overall composition. These deposits are interpreted as tephra ring accumulation formed by dilute density currents that grade upwards to ballistic curtain deposits related to phreatomagmatic-dominated eruptions [87].

\section{El Puesto Member (10c)}

This unit corresponds to the second eruptive episode reported in Petrinovic and Colombo Piñol [20] named in this work as El Puesto member. It is made up of poorly-sorted pyroclastic well-bedded surge deposits previously interpreted as a consequence of a phreatic eruption based on the lack of juvenile clasts [19] (Figure 6c). However, preliminary petrographic analysis of dense non-vesiculated clasts, showing fresh unaltered glassy matrix, suggests their origin as juvenile clasts. This unit crops out at Alto Tocomar, and is distributed following a horseshoe shape geometry (main map). El Puesto member is characterized by a well-developed bedding defined by alternating fines-depleted and lapilli-rich layers, with parallel to low-angle cross-stratified bedforms, accretionary lapilli and bomb sags (Figure 6c). The juvenile content reaches $30 \%$ and is consistently fine-grained; whereas, lithics are mainly made up of lapilli- to bomb-sized fragments of ignimbrites, often hydrothermally altered, basement rocks, and scattered rounded sedimentary pebbles. These pyroclastic deposits are interpreted as related to dilute density currents and to a lesser extent ballistic curtain deposits produced from the collapse of vertically focused dense columns related to phreatomagmatic maar eruption [87].

\subsubsection{La Cantera Formation (Middle-Upper Pleistocene) (11)}

Just outside of the western margin of the Tocomar basin, travertine deposits crop out, Late Pleistocene in age according with radiometric data. These deposits are up to $20 \mathrm{~m}$-thick and cover an area of about $0.15 \mathrm{~km}^{2}$. At the base, lenticular (up to $1 \mathrm{~m}$ thick) alluvial deposits grade laterally into hardened heterometric conglomerates, formed by cobbles and pebbles of volcanic rocks in a brown sandy hardened matrix. This deposit is related mostly to fluvial reworking and transportation of the volcanic succession (Alto Tocomar Formation), alluvial fan deposits (La Vega Formation) and pre-Tocomar basin units. The travertines form an elevated terrace upon the Cerro Aguas Calientes Caldera ignimbrites and due to their geometric relationships with the units that fill up the Tocomar basin has been assigned to the late-stage filling of the basin. Travertines build-up around spring orifices along fractures striking $\mathrm{N} 60^{\circ}$ and expand laterally along the slope forming a series of superimposed flat mounds. Internally, the travertines unit is formed by three main facies. Near ancient vents dense facies finely laminated and coarsely fibrous dominate. In more distal outcrops, dense finely laminated facies are interbedded with lithoclast travertine facies formed by the erosion of previously precipitated travertines, containing a variable proportion of organic matter and clastic material. Our ${ }^{234} \mathrm{U} /{ }^{230} \mathrm{Th}$ geochronological data span within the 126-161 ka interval (Table 1).

\section{Structural Setting}

In the Tocomar basin area, a complex interaction between orogen-parallel thrusts and orogen-oblique COT fault system exists (Figure 2). As the frontal thrusts striking N-S to NNE-SSW begin to bend at Tocomar, the lateral component of COT-like structures increases. In this sense, the structural framework can be divided into two structural patterns according to the main deformation style: transpressive and transtensive. The western sector is dominated by thrust faults and cylindrical to 
stepped non-cylindrical folds involving the Geste Formation. At El Oculto area, the mainly west-vergent high-amplitude folds are aligned NNW-SSE to NW-SE. Conversely, along Tocomar ravine, a N-S trending east-vergent anticline can be observed with the eastern limb vertical to overturned and truncated by a reverse fault that strikes subparallel to the fold trend (Figure 7a). These structures are deflected and merge with major NW-SE-trending left-lateral reverse faults. Basinward, a progressive increase in the extensional component with respect to the reverse component is observed. The southern and eastern areas are dominated by WNW-ESE-trending left lateral strike-slip faults with variable amount of normal and reverse movements. The most prominent structure is the Chorrillos fault, which is interpreted as master fault allowing the development of a possible pull-apart basin, as highlighted by a topographic depression (i.e., basin area). Along the Chorrillos fault, several cold springs are aligned, whereas hot springs are located mostly in the centre of the Tocomar basin. Secondary faults, fractures and veins mapped in the field display an overall strike ranging $\mathrm{N} 20^{\circ}-\mathrm{N} 60^{\circ}$ with steep dip angles $\left(>70^{\circ}\right)$ (Figure $7 \mathrm{~b}$ ). These structures are related to the COT deformation zone and may be interpreted, based on their orientation and sense of movement, as subordinate synthetic (R) and antithetic $\left(R^{\prime}\right)$ shear faults as well as tensile fractures and minor faults. Petrinovic and Colombo [20] recognised also N-S extensional faults, but these structures are limited in extent and are exposed only in the central area, possibly associated with volcano-tectonic faults or ring fault system related to the emplacement of El Puesto member (Figure 7c).

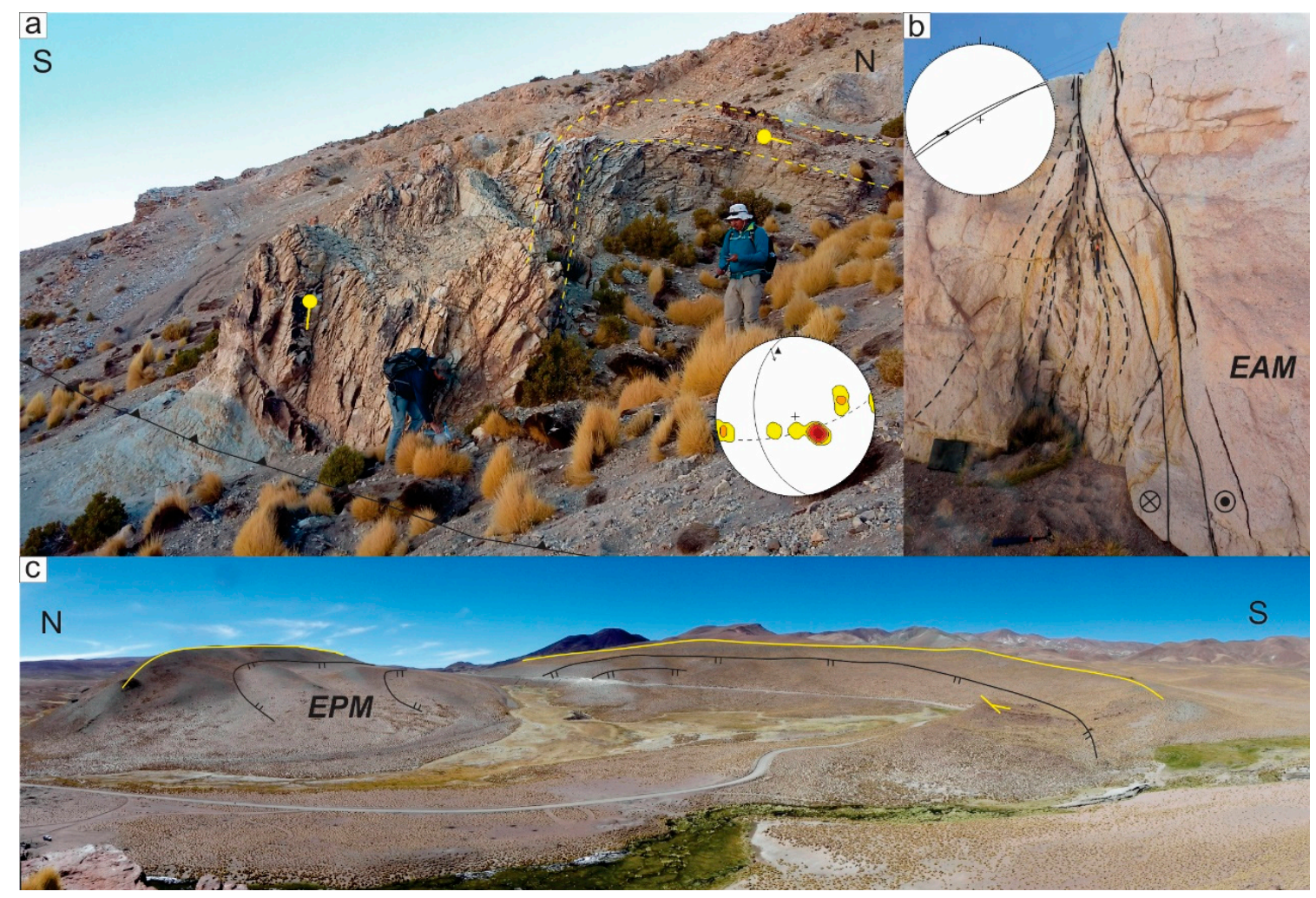

Figure 7. (a) East-vergent inclined fold cut by a forelimb thrust fault developed within the Geste Formation. $\pi$-diagram of poles to bedding $(n=12)$ showing $\pi$-circle (red dashed line) and $\pi$-axis (black triangle). (b) Strike-slip faults (right-lateral with an extensional component) and their associated structures (black dashed lines). (c) Ring-faults surrounding and defining horseshoe geometry of volcaniclastic deposits. Crater rim marked by the yellow solid line. Solid black lines represent faults. Plots are in equal-area stereonet. 


\section{Implications for the Tocomar Geothermal System Investigation}

The geological map of the Tocomar area allowed reconstructing the complex evolution of a small basin including a sustained volcanic activity with different eruptive centres and eruptive styles. Likewise, the lithostratigraphic data improved the definition of a coarsening-upward highly porous sedimentary unit (Geste Formation), previously mapped as Cretaceous Pirgua Subgroup, and allowed us to define for the first time new lithostratigraphic units for the Quaternary sedimentary and volcanic infill of the Tocomar basin. The stratigraphic and structural complexity of the Tocomar area is related to the interaction between orogen-parallel thrusts and orogen-oblique Calama-Olacapato-El Toro (COT) fault system. The geometric relationship between both systems is related to a contemporaneous and kinematically linked growth, e.g., [18], that comprise pure transpressional, mainly along basin-bounding faults, to transtensional deformation style. In addition, the new stratigraphic framework, along with the structural analysis and travertine dating, provide data to assess and improve the knowledge about the geothermal system and fluid circulation.

The thickness $(<230 \mathrm{~m})$ and extent of the Quaternary deposits suggest that the Tocomar basin units do not host the geothermal system and that the reservoir is hosted at deeper depths in the pre-Tocomar units. The recurrent Quaternary volcanic activity (since $0.5 \mathrm{Ma}$ ) suggests the presence of relatively stable magmatic heat source capable of generating a geothermal resource, where the complex structural pattern plays a first-order role in the circulation of hydrothermal fluids. The structures, not only enhance the permeability, but could also constitute the more suitable pathways for deep hydrothermal fluid circulation since at least $\sim 161 \mathrm{ka}$. Conversely, the alignment of cold springs along Chorrillos fault plane suggests limited circulation because the barrier-conduit hydraulic behaviour of the thrust faults. However, the full understanding of the structural evolution and the relationship with the Tocomar geothermal system need more research in order to generate an accurate conceptual model aimed to reduce the uncertainty and risks during advanced exploration stages. In this sense, this new geological map is a fundamental first step that can encourage geothermal exploration and exploitation that can largely mitigate local socio-economic problems and provide an energy alternative for the region. In addition, this map can be the fundamental support for in depth studies of the area and, combined with geophysical, geochemical and structural data, for obtaining a 3D model of the geothermal system.

Supplementary Materials: The following are available online at http://www.mdpi.com/1996-1073/13/20/5492/s1, Figure S1: Geology of the Tocomar basin.

Author Contributions: Conceptualization, R.F., W.B. and G.G. (Gianluca Groppelli); methodology, G.G. (Gianluca Groppelli), W.B., G.D.A. and G.G. (Guido Giordano); validation, R.B., S.C., G.N. and G.G. (Guido Giordano); formal analysis, C.C., R.F. and S.T.; investigation, R.F., W.B., G.G. (Gianluca Groppelli), F.A., L.A., S.B., C.C., A.C., G.D.A., A.A.D.B., C.I., G.N., S.T. and G.G. (Guido Giordano); resources, G.B. and M.S.; data curation, R.F., G.G. (Gianluca Groppelli); writing—original draft preparation, R.F., W.B.; writing-review and editing, R.F., W.B., G.G. (Gianluca Groppelli), L.A., G.G. (Guido Giordano); visualization, R.F., G.G. (Gianluca Groppelli); supervision, W.B., G.G. (Gianluca Groppelli); project administration, G.G. (Guido Giordano) and J.G.V.; funding acquisition, G.G. and J.G.V. All authors have read and agreed to the published version of the manuscript.

Funding: This research was funded by the Progetto di Grande Rilevanza MAE (Italy) MINCyT (Argentina) "Sviluppo sostenibile dei sistemi geotermici associati ai sistemi vulcanici della Puna nelle Province di Salta e Jujuy" (2014-2016; Resp. G. Giordano and J.G.V.); PIO N 3320140100015CO “Caracterización del Sistema Geotermal Tocomar y evaluación de su potencial como recurso energético no convencional sustentable para la Puna Argentina (YTEC; 2015-2017)". GN field work has been supported by Italgas project funds.

Acknowledgments: The authors gratefully acknowledge logistical and technical support from Instituto GEONORTE. R.F. would like to thanks R. Seggiaro and A. Villagrán for useful discussions on the stratigraphy/ structural framework of the central Puna.

Conflicts of Interest: The authors declare no conflict of interest. 


\section{References}

1. Fridleifsson, I.B. Status of geothermal energy amongst the world's energy sources. Geothermics 2003, 32, 379-388. [CrossRef]

2. Bertani, R. Geothermal power generation in the world 2010-2014 update report. Geothermics 2016, 60, 31-43. [CrossRef]

3. Vieira, F.; Hamza, V. Assessment of Geothermal Resources of South America-A New Look. Int. J. Terr. Heat Flow Appl. Geotherm. 2019, 2, 46-57. [CrossRef]

4. Chiodi, A.; Tassi, F.; Báez, W.; Maffucci, R.; Invernizzi, C.; Giordano, G.; Corrado, S.; Bicocchi, G.; Vaselli, O.; Viramonte, J.G.; et al. New geochemical and isotopic insights to evaluate the geothermal resource of the hydrothermal system of Rosario de la Frontera (Salta, northern Argentina). J. Volcanol. Geotherm. Res. 2015, 295, 16-25. [CrossRef]

5. Maffucci, R.; Bigi, S.; Corrado, S.; Chiodi, A.; Di Paolo, L.; Giordano, G.; Invernizzi, C. Quality assessment of reservoirs by means of outcrop data and 'discrete fracture network' models: The case history of Rosario de La Frontera (NW Argentina) geothermal system. Tectonophysics 2015, 647, 112-131. [CrossRef]

6. Sanchez-Alfaro, P.; Sielfeld, G.; Campen, B.; Van Dobson, P.; Fuentes, V.; Reed, A.; Palma-Behnke, R.; Morata, D. Geothermal barriers, policies and economics in Chile-Lessons for the Andes. Renew. Sustain. Energy Rev. 2015, 51, 1390-1401. [CrossRef]

7. Chiodi, A.L.; Filipovich, R.E.; Esteban, C.; Pesce, A.H. Geothermal Country Update of Argentina: 2015-2020. In Proceedings of the World Geotermal Congress 2020, Reykjavik, Iceland, 27 April-1 May 2020.

8. Giordano, G.; Pinton, A.; Cianfarra, P.; Baez, W.; Chiodi, A.; Viramonte, J.; Norini, G.; Groppelli, G. Structural control on geothermal circulation in the Cerro Tuzgle-Tocomar geothermal volcanic area (Puna plateau, Argentina). J. Volcanol. Geotherm. Res. 2013, 249, 77-94. [CrossRef]

9. Barcelona, H.; Favetto, A.; Peri, V.G.; Pomposiello, C.; Ungarelli, C. The potential of audiomagnetotellurics in the study of geothermal fields: A case study from the northern segment of the La Candelaria Range, northwestern Argentina. J. Appl. Geophys. 2013, 88, 83-93. [CrossRef]

10. Invernizzi, C.; Pierantoni, P.P.; Chiodi, A.; Maffucci, R.; Corrado, S.; Baez, W.; Tassi, F.; Giordano, G.; Viramonte, J. Preliminary assessment of the geothermal potential of Rosario de la Frontera area (Salta, NW Argentina): Insight from hydro-geological, hydro-geochemical and structural investigations. J. S. Am. Earth Sci. 2014, 54, 20-36. [CrossRef]

11. Maffucci, R.; Corrado, S.; Aldega, L.; Bigi, S.; Chiodi, A.; Di Paolo, L.; Giordano, G.; Invernizzi, C. Cap rock efficiency of geothermal systems in fold-and-thrust belts: Evidence from paleo-thermal and structural analyses in Rosario de La Frontera geothermal area (NW Argentina). J. Volcanol. Geotherm. Res. 2016, 328, 84-95. [CrossRef]

12. Chiodi, A.L.; Báez, W.A.; Filipovich, R.E.; Ahumada, M.F.; Viramonte, J.G. Preliminary conceptual model of the El Sauce geothermal system (Salta) from fluid geochemistry investigations. Rev. Asoc. Geol. Argent. 2016, 73, 93-103.

13. Chiodi, A.; Tassi, F.; Báez, W.; Filipovich, R.; Bustos, E.; Galli, M.G.; Suzaño, N.; Ahumada, M.F.; Viramonte, J.G.; Giordano, G.; et al. Preliminary conceptual model of the Cerro Blanco caldera-hosted geothermal system (Southern Puna, Argentina): Inferences from geochemical investigations. J. S. Am. Earth Sci. 2019, 94, 102213. [CrossRef]

14. Giordano, G.; Ahumada, F.; Aldega, L.; Baez, W.; Becchio, R.; Bigi, S.; Caricchi, C.; Chiodi, A.; Corrado, S.; De Benedetti, A.A.; et al. Preliminary Data on the Structure and Potential of the Tocomar Geothermal Field (Puna Plateau, Argentina). Energy Procedia 2016, 97, 202-209. [CrossRef]

15. Ricci, M.; Figueroa, L.A. Fotolineamientos y Mineralización en el Noroeste Argentino; Ministerio de Economía, Secretaría de Minería, Dirección Nacional de Geología y Minería, Ed.; Servicio Geológico Minero Argentino: Buenos Aires, Argentina, 1971.

16. Alonso, R.N.; Viramonte, J.; Gutiérrez, R. Puna Austral. Bases para el subprovincialismo geológico de la Puna argentina. In Proceedings of the IX Congreso Geológico Argentino, San Carlos de Bariloche, Argentina, 5-9 November 1984; Volume 1, pp. 43-63.

17. Salfity, J.A. Lineamentos transversales al rumbo andino en el Noroeste Argentino. In Proceedings of the IV Congreso Geologico Chileno, Antofagasta, Chile, 19-24 August 1985; Volume 2, pp. 119-137. 
18. Norini, G.; Baez, W.; Becchio, R.; Viramonte, J.; Giordano, G.; Arnosio, M.; Pinton, A.; Groppelli, G. The Calama-Olacapato-El Toro fault system in the Puna Plateau, Central Andes: Geodynamic implications and stratovolcanoes emplacement. Tectonophysics 2013, 608, 1280-1297. [CrossRef]

19. Petrinovic, I.A.; Arnosio, J.M.; Alvarado, G.E.; Guzmán, S. Erupciones freáticas sintectónicas en el campo geotérmico de Tocomar, Salta. Rev. Asoc. Geol. Argent. 2005, 60, 132-141.

20. Petrinovic, I.A.; Piñol, F.C. Phreatomagmatic and phreatic eruptions in locally extensive settings of Southern Central Andes: The Tocomar Volcanic Centre $\left(24^{\circ} 10^{\prime}\right.$ S $\left.-66^{\circ} 34^{\prime} \mathrm{W}\right)$, Argentina. J. Volcanol. Geotherm. Res. 2006, 158, 37-50. [CrossRef]

21. Petrinovic, I.A.; Riller, U.; Brod, J.A.; Alvarado, G.; Arnosio, M. Bimodal volcanism in a tectonic transfer zone: Evidence for tectonically controlled magmatism in the southern Central Andes, NW Argentina. J. Volcanol. Geotherm. Res. 2006, 152, 240-252. [CrossRef]

22. Sainato, C.M.; Febrer, J.M.; Pomposiello, M.C.; Mamani, M.; Maidana, A. Magnetotelluric Study of the Tuzgle Volcano Zone, Jujuy Province, Argentina. J. Geomagn. Geoelectr. 1993, 45, 787-803. [CrossRef]

23. Ahumada, M.F.; Favetto, A.; Filipovich, R.E.; Chiodi, A.; Báez, W.; Viramonte, J.G.; Guevara, L. Aplicación del método magnetotelúrico en la exploración del sistema geotermal Tocomar (Puna, NO Argentina). In Proceedings of the XX Congreso Geológico Argentino, San Miguel de Tucumán, Argentina, 7-11 August 2017; pp. 3-8.

24. Schurr, B.; Rietbrock, A.; Asch, G.; Kind, R.; Oncken, O. Evidence for lithospheric detachment in the central Andes from local earthquake tomography. Tectonophysics 2006, 415, 203-223. [CrossRef]

25. Aquater, S.A. Exploración Geotérmica del Área del Cerro Tuzgle; Secretaría de Estado de Minería: Provincia de Jujuy, Argentina, 1980; Unpublished Work.

26. Ferretti, J.; Alonso, R.N. Geoquímica del campo geotérmico Tocomar (Salta). In Proceedings of the XII Congreso Geológico Argentino: II Congreso de Exploración de Hidrocarburos, Mendoza, Argentina, 10-15 October 1993.

27. Taviani, S. Studio Geo-Petrografico Dell'Area di Tocomar, Puna Argentina, Tra S. Antonio de Los Cobres e Olacapato. Master's Thesis, Universita’Degli Studi di Roma La Sapienza, Rome, Italy, 1998.

28. Coira, B.L. Recursos Geotérmicos de Alta Entalpía de la Provincia de Jujuy. In Proceedings of the XVII Congreso Geológico Argentino, San Salvador de Jujuy, Argentina, 7-10 October 2008; pp. 563-576.

29. Blasco, G.; Zappettini, E.O.; Hongn, F. Hoja Geológica 2566-I, San Antonio de los Cobres; Boletin 21; Servicio Geológico Minero Argentino: Buenos Aires, Argentina, 1996.

30. Seggiaro, R.E.; Becchio, R.; Bercheñi, V.; Ramallo, L.; Franchi, M. Hoja Geológica 2366-III Susques; Boletin 41; Servicio Geológico Minero Argentino: Buenos Aires, Argentina, 2015; ISBN 0328-2333.

31. Vilela, C.R. Descripción Geológica de la Hoja 6c, San Antonio de los Cobres: Provincias de Salta y Jujuy; Servicio Nacional Minero Geológico: Buenos Aires, Argentina, 1969.

32. Lanza, F.; Tibaldi, A.; Bonali, F.L.; Corazzato, C. Space-time variations of stresses in the Miocene-Quaternary along the Calama-Olacapato-El Toro Fault Zone, Central Andes. Tectonophysics 2013, 593, 33-56. [CrossRef]

33. Bonali, F.L.; Corazzato, C.; Tibaldi, A. Elastic stress interaction between faulting and volcanism in the Olacapato-San Antonio de Los Cobres area (Puna plateau, Argentina). Glob. Planet. Chang. 2012, 90-91, 104-120. [CrossRef]

34. Isacks, B.L. Uplift of the central Andean Plateau and bending of the Bolivian Orocline. J. Geophys. Res. 1988, 93, 3211-3231. [CrossRef]

35. Kay, S.M.; Coira, B.; Viramonte, J. Young mafic back arc volcanic rocks as indicators of continental lithospheric delamination beneath the Argentine Puna Plateau, central Andes. J. Geophys. Res. Solid Earth 1994, 99, 24323-24339. [CrossRef]

36. Allmendinger, R.W.; Jordan, T.E.; Kay, S.M.; Isacks, B.L. The Evolution of the Altiplano-Puna Plateau of the Central Andes. Annu. Rev. Earth Planet. Sci. 1997, 25, 139-174. [CrossRef]

37. Coutand, I.; Cobbold, P.R.; De Urreiztieta, M.; Gautier, P.; Chauvin, A.; Gapais, D.; Rossello, E.A.; López-Gamundí, O. Style and history of Andean deformation, Puna plateau, northwestern Argentina. Tectonics 2001, 20, 210-234. [CrossRef]

38. Riller, U.; Oncken, O. Growth of the central Andean plateau by tectonic segmentation is controlled by the gradient in crustal shortening. J. Geol. 2003, 111, 367-384. [CrossRef] 
39. Kay, S.M.; Coira, B.L. Shallowing and steepening subduction zones, continental lithospheric loss, magmatism, and crustal flow under the Central Andean Altiplano-Puna Plateau. In Geological Society of America Memoir; Geological Society of America: Boulder, CO, USA, 2009; Volume 204, pp. 229-259.

40. Guzmán, S.; Grosse, P.; Montero-López, C.; Hongn, F.; Pilger, R.; Petrinovic, I.A.; Seggiaro, R.; Aramayo, A. Spatial-temporal distribution of explosive volcanism in the $25-28^{\circ} \mathrm{S}$ segment of the Andean Central Volcanic Zone. Tectonophysics 2014, 636, 170-189. [CrossRef]

41. Viramonte, J.G.; Galliski, M.A.; Saavedra, V.A.; Aparicio, A.; García-Cacho, G.L.; Escorza, C.M. El finivulcanismo básico de la depresión de Arizaro, provincia de Salta. In Proceedings of the IX Congreso Geológico Argentino, San Carlos de Bariloche, Argentina, 5-9 November 1984; Volume 3, pp. $234-251$.

42. Viramonte, J.G.; Petrinovic, I.A. Calderas asociadas a megafracturas transcurrentes en los Andes Centrales del Sur. In Proceedings of the XI Congreso Geologico Argentino, San Juan, Argentina, 17-21 September 1990; pp. 369-372.

43. Petrinovic, I.A.; Mitjavila, J.; Viramonte, J.G.; Becchio, R.; Arnosio, M. Descripción geoquímica y geocronológica de secuencias volcánicas neógenas de Trasarco, en el extremo oriental de la Cadena Volcánica Transversal del Quevar (Noroeste de Argentina). Acta Geol. Hisp. 1999, 34, 255-272.

44. Riller, U.; Petrinovic, I.A.; Ramelow, J.; Strecker, M.; Oncken, O. Late cenozoic tectonism, collapse caldera and plateau formation in the Central Andes. Earth Planet. Sci. Lett. 2001, 188, 299-311. [CrossRef]

45. Matteini, M.; Mazzuoli, R.; Omarini, R.; Cas, R.; Maas, R. Geodynamical evolution of Central Andes at $24^{\circ} \mathrm{S}$ as inferred by magma composition along the Calama-Olacapato-El Toro transversal volcanic belt. J. Volcanol. Geotherm. Res. 2002, 118, 205-228. [CrossRef]

46. Trumbull, R.B.; Riller, U.; Oncken, O.; Scheuber, E.; Munier, K.; Hongn, F. The time-space distribution of Cenozoic volcanism in the South-Central Andes: A new data compilation and some tectonic implications. In The Andes; Springer: Berlin, Germany, 2006; pp. 29-43. [CrossRef]

47. Acocella, V.; Gioncada, A.; Omarini, R.; Riller, U.; Mazzuoli, R.; Vezzoli, L. Tectonomagmatic characteristics of the back-arc portion of the Calama-Olacapato-El Toro Fault Zone, Central Andes. Tectonics 2011, 30, TC3005. [CrossRef]

48. Norini, G.; Cogliati, S.; Baez, W.; Arnosio, M.; Bustos, E.; Viramonte, J.; Groppelli, G. The geological and structural evolution of the Cerro Tuzgle Quaternary stratovolcano in the back-arc region of the Central Andes, Argentina. J. Volcanol. Geotherm. Res. 2014, 285, 214-228. [CrossRef]

49. Turner, J.C.M. Descripción Geológica de la Hoja 7 c, Nevado de Cachi, Provincia de Salta: Carta Geologico-Economica de la Republica Argentina, Escala 1: 200.000; Dirección Nacional de Geología y Minería: Buenos Aires, Argentina, 1964; Volume 99.

50. Aceñolaza, F.; Aceñolaza, G. La Formación Puncoviscana y unidades estratigráficas vinculadas en el Neoproterozoico-Cámbrico temprano del Noroeste Argentino. Lat. Am. J. Sedimentol. Basin Anal. 2005, 12, 65-87.

51. Sánchez, M.C.; Salfity, J.A. La cuenca cámbrica del Grupo Mesón en el Noroeste Argentino: Desarrollo estratigráfico y paleogeográfico. Acta Geol. Hisp. 1999, 34, 123-139.

52. Aceñolaza, F.G.; Buatois, L.A.; Mángano, M.G.; Esteban, S.B.; Tortello, M.F.; Aceñolaza, G.F. Cámbrico y Ordovícico del noroeste argentino. In Geología Argentina; Instituto de Geología y Recursos Minerales: Buenos Aires, Argentina, 1999; Volume 29, pp. 169-187.

53. Suzaño, N.; Becchio, R.; Sola, A.; Ortiz, A.; Nieves, A.; Quiroga, M.; Fuentes, G. The role of magma mixing in the evolution of the Early Paleozoic calc-alkaline granitoid suites. Eastern magmatic belt, Puna, NW Argentina. J. S. Am. Earth Sci. 2017, 76, 25-46. [CrossRef]

54. Coira, B. Ciclo efusivo ordovícico registrado en la Formación Acoite, Abra Pampa, Provincia de Jujuy, Argentina. In Proceedings of the II Congreso Iberoamericano de Geología Económica, Buenos Aires, Argentina, 15-19 December 1975; Volume 1, pp. 37-56.

55. Méndez, V.; Navarini, A.; Plaza, D.; Viera, V. Faja eruptiva de la Puna oriental. In Proceedings of the V Congreso Geológico Argentino, Córdoba, Argentina, 22-28 October 1973; pp. 147-158.

56. Allmendinger, R.W.; Ramos, V.A.; Jordan, T.E.; Palma, M.; Isacks, B.L. Paleogeography and Andean structural geometry, northwest Argentina. Tectonics 1983, 2, 1-16. [CrossRef]

57. Viramonte, J.M.G.; Becchio, R.A.; Viramonte, J.M.G.; Pimentel, M.M.; Martino, R.D. Ordovician igneous and metamorphic units in southeastern Puna: $\mathrm{New} \mathrm{U}-\mathrm{Pb}$ and $\mathrm{Sm}-\mathrm{Nd}$ data and implications for the evolution of northwestern Argentina. J. S. Am. Earth Sci. 2007, 24, 167-183. [CrossRef] 
58. Turner, J.C.M. Estratigrafía del Nevado de Cachi y sector al oeste (Salta). Acta Geol. Lilloana 1960, 3, $191-226$.

59. Schwab, K.; Lippolt, H. K-Ar mineral ages and late Cenozoic history of the Solar de Cauchari area (Argentina Puna). In Proceedings of the Symposium on Andean and Antartic Volcanology Problems; Gonzales-Ferra, O., Ed.; International Association of Volcanology and Chemistry of the Earth's Interior Santiago: Rome, Italy, 2008; Volume 1, pp. 39-85.

60. Koukharsky, M.; Munizga, F. Los volcanes Guanaquero, Chivinar, Tul Tul, del medio y Pocitos, Provincia de Salta. Litologia y edades K/Ar. In Proceedings of the XI Congreso Geologico Argentino, San Juan, Argentina, 17-21 September 1990; Volume 1, pp. 54-57.

61. Alonso, R.N. Estratigrafía del Cenozoico de la cuenca de Pastos Grandes (Puna Salteña) con énfasis en la Formación Sijes y sus boratos. Rev. Asoc. Geol. Argent. 1992, 47, 189-199.

62. Hongn, F.; del Papa, C.; Powell, J.; Petrinovic, I.A.; Mon, R.; Deraco, V. Middle Eocene deformation and sedimentation in the Puna-Eastern Cordillera transition $\left(23^{\circ}-26^{\circ} \mathrm{S}\right)$ : Control by preexisting heterogeneities on the pattern of initial Andean shortening. Geology 2007, 35, 271-274. [CrossRef]

63. Carrapa, B.; DeCelles, P.G. Eocene exhumation and basin development in the Puna of northwestern Argentina. Tectonics 2008, 27, TC1015. [CrossRef]

64. DeCelles, P.G.; Carrapa, B.; Gehrels, G.E. Detrital zircon U-Pb ages provide provenance and chronostratigraphic information from Eocene synorogenic deposits in northwestern Argentina. Geology 2007, 35, 323-326. [CrossRef]

65. Goddard, P.; Willson, J.J.; Couch, S.; Viramonte, J. The evolution of El Quevar volcanic complex, Salta Province, Argentina. In Proceedings of the XIV Congreso Geológico Argentino, Salta, Argentina, 19-24 September 1999; Volume 2, pp. 225-227.

66. Matteini, M.; Mazzuoli, R.; Omarini, R.; Cas, R.; Maas, R. The geochemical variations of the upper cenozoic volcanism along the Calama-Olacapato-El Toro transversal fault system in central Andes ( 24 B S): Petrogenetic and geodynamic implications. Tectonophysics 2002, 345, 211-227. [CrossRef]

67. Norini, G.; Bustos, E.; Arnosio, M.; Baez, W.; Zuluaga, M.C.; Roverato, M. Unusual volcanic instability and sector collapse configuration at Chimpa volcano, central Andes. J. Volcanol. Geotherm. Res. 2020, 393, 106807. [CrossRef]

68. Petrinovic, I.A.; Martí, J.; Aguirre-Díaz, G.J.; Guzmán, S.; Geyer, A.; Paz, N.S. The Cerro Aguas Calientes caldera, NW Argentina: An example of a tectonically controlled, polygenetic collapse caldera, and its regional significance. J. Volcanol. Geotherm. Res. 2010, 194, 15-26. [CrossRef]

69. Petrinovic, I.A.; Riller, U.; Brod, J.A. The Negra Muerta Volcanic Complex, southern Central Andes: Geochemical characteristics and magmatic evolution of an episodically active volcanic centre. J. Volcanol. Geotherm. Res. 2005, 140, 295-320. [CrossRef]

70. Déruelle, B. Petrology of Quaternary shoshonitic lavas of northwestern Argentina. Geol. Soc. Am. Spec. Pap. 1991, 265, 201-216. [CrossRef]

71. Salvador, A. International Stratigraphic Guide: A Guide to Stratigraphic Classification, Terminology, and Procedure; Geological Society of America: Rome, Italy, 2008; Volume 1, pp. 39-85.

72. Funiciello, R.; Giordano, G. La nuova carta geologica di Roma: Litostratigrafia e organizzazione stratigrafica. In La Geologia di Roma dal Centro Storico alla Periferia; Funicello, R., Praturlon, A., Giordano, G., Eds.; SELCA: Rome, Italy, 2008; Volume 1, pp. 39-85.

73. Giordano, G.; De Benedetti, A.A.; Diana, A.; Diano, G.; Esposito, A.; Fabbri, M.; Gaudioso, F.; Marasco, F.; Mazzini, I.; Miceli, M. Stratigraphy, volcano tectonics and evolution of the Colli Albani volcanic field. In The Colli Albani Volcano; Geological Society of London: London, UK, 2010; pp. 43-97.

74. Branca, S.; Coltelli, M.; Groppelli, G.; Lentini, F. Geological map of Etna volcano, 1:50,000 scale. Ital. J. Geosci. 2011, 130, 265-291. [CrossRef]

75. Sánchez, L.G.; Macías, J.L.; Sulpizio, R.; Osorio-Ocampo, L.S.; Pellicioli, C.; Pola, A.; Avellan, D.R.; Cisneros, G.; García, F.; Ocampo-Díaz, Y.Z.E. Geology of La Reforma caldera complex, Baja California, Mexico. J. Maps 2019, 15, 487-498. [CrossRef]

76. Wedepohl, K.H. The composition of the continental crust. Geochim. Cosmochim. Acta 1995, 59, 1217-1232. [CrossRef]

77. Edwards, R.L.; Chen, J.H.; Wasserburg, G.J. 238U-234U-230Th-232Th systematics and the precise measurement of time over the past 500,000 years. Earth Planet. Sci. Lett. 1987, 81, 175-192. [CrossRef] 
78. Coira, B.; Davidson, J.; Mpodozis, C.; Ramos, V. Tectonic and magmatic evolution of the Andes of northern Argentina and Chile. Earth-Sci. Rev. 1982, 18, 303-332. [CrossRef]

79. Schwab, K. Contribución al conocimiento del sector occidental de la cuenca sedimentaria del Grupo Salta (Cretácico-Eogénico) en el noroeste argentino. In Proceedings of the IX Congreso Geológico Argentino, San Carlos de Bariloche, Argentina, 5-9 November 1984; Volume 1, pp. 586-604.

80. Sabino, I.F. Geología del Subgrupo Pirgua (Cretácico) del Noroeste Argentino. Ph.D. Thesis, Universidad Nacional de Salta, Salta, Argentina, 2002; 260p. Inédito.

81. Marquillas, R.A.; del Papa, C.; Sabino, I.F. Sedimentary aspects and paleoenvironmental evolution of a rift basin: Salta Group (Cretaceous-Paleogene), northwestern Argentina. Int. J. Earth Sci. 2005, 94, 94-113. [CrossRef]

82. Seggiaro, R.E.; Guzmán, S.R.; Apaza, F.D. Control estructural sobre el magmatismo en los alrededores de San Antonio de los Cobres, sector oriental de la Puna Central. In Proceedings of the XX Congreso Geológico Argentino, San Miguel de Tucumán, Argentina, 7-11 August 2017; pp. 142-146.

83. Coira, B.L.; Paris, G. Estratigrafía volcánica del área del cerro Tuzgle, Provincias de Jujuy y Salta. In Proceedings of the VIII Congreso Geologico Argentino, San Luis, Argentina, 20-26 September 1981; Volume III, pp. 659-671.

84. Robl, K.; de Brodtkorb, M.K.; Ametrano, S. La mineralización epitermal miocena del complejo estratovolcánico Quevar, Salta. Rev. Asoc. Geol. Argent. 2009, 64, 525-539.

85. Aramayo, V.M.B. Estilos Eruptivos y Evolución del Centro Volcánico San Gerónimo, Puna Central (Provincia de Salta). Master's Thesis, Universidad Nacional de Salta, Salta, Argentina, 2017.

86. Murcia, H.F.; Borrero, C.A.; Pardo, N.; Alvarado, G.E.; Arnosio, M.; Scolamacchia, T. Depósitos Volcaniclásticos: Términos Y Conceptos Para Una Clasificación En Español Volcaniclastic Deposits: Terminology and Concepts for a Classification in Spanish. Rev. Geol. Am. Cent. 2013, 48, 15-39. [CrossRef]

87. Graettinger, A.H.; Valentine, G.A. Evidence for the relative depths and energies of phreatomagmatic explosions recorded in tephra rings. Bull. Volcanol. 2017, 79, 88. [CrossRef]

Publisher's Note: MDPI stays neutral with regard to jurisdictional claims in published maps and institutional affiliations.

(C) 2020 by the authors. Licensee MDPI, Basel, Switzerland. This article is an open access article distributed under the terms and conditions of the Creative Commons Attribution (CC BY) license (http://creativecommons.org/licenses/by/4.0/). 